\title{
ASSESSMENT OF STUDENT LEARNING
}

\section{Dragana Koceva, Biljana Petkovska}

\author{
University" Goce Delcev" \\ Stip, Republic of Macedonia \\ dragana.koceva@ugd.edu.mk; biliana.petkovska@ugd.edu.mk
}

\begin{abstract}
:
Rapid technical-technological development inevitably imposes many changes that are introduced in all spheres of our life including the educational process. The changes in the educational process are mostly represented by the organization of the learning technology and the assessment of the students.

One of the most important questions for the assessment of the students in the education is connected with the efficiency of the education or its rationality and economy, what effects are reached and how much they are appropriate to the given efforts, goals and time. According to efficiency there are different opinions about the traditional and modern concept of learning.

Subject of our interest is the assessment of students learning especially the difference between their traditional and modern evaluation.

Which way of assessment is better, traditional or the modern one? Which are the advantages and disadvantages?

Our goal is to make cohesion between the two ways, because each of them affects the assessment improvement.
\end{abstract}

Key words: assessment, traditional, modern

\section{COHESION BETWEEN TRADITIONAL AND MODERN WAY OF ASSSESSMENT - IS THERE ANY OR NOT?}

Every human activity finishes with perception and analysis of the results. In the teaching process, as an activity with particular purpose and tasks also appears confirmation of the results of teachers and students common work, especially for confirmation of the quantity and the quality in the students' knowledge, their relation to work and improvement in certain period of time.

In the last few years in our country we speak more loudly about the changes in the education. Even though there is agreement about the need for changes in education, at present we can hear opposite attitudes about what should be changed and in which direction, how the changes should be made, the dynamics of realization of those changes, priorities, etc. Urgings for changes especially those of innovative nature do not begin from the negative grade about today situation, but also from the fact that it is necessary to have development educational directions in agreement with changes in society and the newest scientific research for better education.

In today circumstances education is divided into traditional and modern and by that a question is being asked about what will happen with the ways of assessment, do they change or they stay the same. Because of this, we should first make a comparison of traditional and modern classes, see the differences and similarities, and analyze the way of evaluation.

Traditional education is usually claimed to be more efficient, especially for the adoption of knowledge. This is explained by the fact that for a relative period of time some results about something being learnt can be seen. And really, in this type of education students learn very quickly what the lesson is about during classes and at home. They actually remember the given knowledge and after that they show what they have learned. They learn almost on every class, accumulate their knowledge, habits and when they do that, the aim is very highly productive.

But this highly productive effectiveness of the traditional education is just plausible because of the following:

- $\quad$ Big part of the learned material is adopted outside the classes; 
- What is quickly learned, quickly can be forgotten;

- $\quad$ Cognitive component is also reduced;

- $\quad$ Pedagogical component is neglected;

When we speak about modern education we must say that is still very difficult to see its clear concept. That is why modern knowledge can be seen only in comparison with the traditional one. As it is said before that traditional way of knowledge is with plausible efficiency, the modern one also has some disadvantages that should be mentioned:

- $\quad$ Students included in this kind of education will not have the same knowledge as those in traditional one.

- $\quad$ Freedom given to students is too great.

Table 1: Basic tendencies foe educational changes

\begin{tabular}{|c|c|c|}
\hline Educational components & Traditional way of education & Modern way of education \\
\hline Psychological- theoretical basis & $\begin{array}{l}\text { Bihevioristic - associationistic } \\
\text { theories }\end{array}$ & $\begin{array}{l}\text { Persons cognitive and } \\
\text { humanistic theories }\end{array}$ \\
\hline Aim & Accumulation of knowledge & Development of persons abilities \\
\hline Plans and programs & $\begin{array}{l}\text { Centralistic, universal and rigid } \\
\text { plans and programs }\end{array}$ & Flexible plans and programs \\
\hline Organization & Rigid class system & $\begin{array}{l}\text { Different and more elastic } \\
\text { organizational forms }\end{array}$ \\
\hline Educational resources & $\begin{array}{l}\text { Demonstrative and artificial } \\
\text { educational resources }\end{array}$ & $\begin{array}{l}\text { Natural and workable } \\
\text { educational resources }\end{array}$ \\
\hline $\begin{array}{l}\text { Methods of teaching and } \\
\text { learning }\end{array}$ & $\begin{array}{l}\text { Methods of direct teaching } \\
\text { Methods of passive learning }\end{array}$ & $\begin{array}{l}\text { Methods of indirect learning } \\
\text { Methods of active learning }\end{array}$ \\
\hline Teacher's role & $\begin{array}{l}\text { Program realizer } \\
\text { User of the results of different } \\
\text { researches } \\
\text { Keeper of the order and } \\
\text { discipline }\end{array}$ & $\begin{array}{l}\text { Practical man who thinks and } \\
\text { plans } \\
\text { Active researcher in his } \\
\text { educational class } \\
\text { Democrat } \\
\text { Organizer of the order and } \\
\text { discipline }\end{array}$ \\
\hline Student's role & $\begin{array}{l}\text { Passive hearer } \\
\text { Mostly external motivated }\end{array}$ & $\begin{array}{l}\text { Active hearer in the educational } \\
\text { process } \\
\text { Mostly internal motivated }\end{array}$ \\
\hline Monitoring and evaluation & $\begin{array}{l}\text { Summative with an accent to } \\
\text { quantitative results(knowledge) }\end{array}$ & $\begin{array}{l}\text { Diagnostic, formative and } \\
\text { summative with the same accent } \\
\text { on the result (knowledge) and } \\
\text { process (students development) }\end{array}$ \\
\hline
\end{tabular}

Evaluation and assessment of the students' knowledge is complicated work, and lately for this stage of teaching different opinions are defined. Some practitioners propose regular assessment and often with different forms and instruments of evaluation, and others propose that assessment should be annulled. By chronology, there have always been different demands and views about the forms of evaluation, and also pressure imposed by parents and sometimes students themselves. Many theoreticians put great psychological stress on the students and on their parents with arguments about the school manner of assessment. There are five important assumptions that we have made about the evaluation:

- How real the grade is and how it stimulates the student to use his intellectual abilities, and how this is a function of evaluation;

- Is the aim of students' evaluation for them to be informed and stimulated to develop their intellectual abilities? 
- $\quad$ How much the students are stimulated by the grade to develop their capabilities, individual abilities and potential;

- How do we form the grade?

- Which way of assessment is better, the traditional or the modern one?

Some possible answers and explanations to these questions will be given next, based on our personal experience and some research too.

\subsection{ASSESSMENT - PROFESSIONAL JUDGMENT}

Professional judgment is the foundation for all assessment. The measurement of student performance may seem "objective," given such practices as machine scoring and multiple--choice test items, but even these approaches are based on professional assumptions and values.

Whether that judgment occurs in constructing test questions, scoring essays, creating rubrics, grading participation, combining scores, or interpreting standardized test scores, the essence of the process is making professional interpretations and decisions.

\subsection{SEPARATE BUT RELATED PRINCIPLES OF MEASUREMENT EVIDENCE AND EVALUATION ARE BASE FOR THE ASSESSMENT}

It is important to understand the difference between measurements evidence (differentiating degrees of a trait by description or by assigning scores) and evaluation (interpreting the description or scores). Essential measurement evidence skills include the ability to understand and interpret the meaning of descriptive statistical procedures, including variability, correlation, percentiles, standard scores, growth--scale score and principles of combining scores for grading. A conceptual understanding of these techniques is needed for such tasks as interpreting student strengths and weaknesses, examining reliability and validity evidence, determining grades, and making admissions decisions. Many researches have indicated that these concepts and techniques comprise part of an essential language for educators.

They also provide a common basis for communication about results, interpretation of evidence, and appropriate use of data. This is increasingly important because the pervasiveness of standards-based, high--stakes, large-scale assessments is given. Evaluation concerns merit and worth of the data as applied to a specific use or context.

\subsection{METHODS FOR GRADE FORMING}

Grade forming for the students' achievements in a certain subject and for a specific period of time should be performed according to the procedures that allow the grade to be a real representation of the students' achievements. It understands certain summaries of one or more evaluations put together and forming the appropriate level of grade.

1.3.1. Methods for forming a grade should be regulated by the standards and policies of the schools in one country.

- $\quad$ All teachers in a school should know and use the standards of grading in the same way.

- $\quad$ The school policy for forming a grade should be familiar to and accepted by all teachers.

- $\quad$ The school is obliged to introduce the ways of grading to students and their parents.

1.3.2. Achievements of the student, his/her skills and knowledge, hard work, his/her behavior and active learning should be graded separately.

1.3.3. The grade should be formed according to the data gathered by the teacher during the grading period.

- When we form a grade, we should take into consideration all the answers that student gave about the educational themes.

- The grade for each period of evaluation should be based on more testing of the students and this should be done by using different methods.

- We should form an appropriate description of the student's results in order to get a summative grade. 
1.3.4. The criteria for forming a grade should be clearly defined and based on the aims of the educational programs.

- $\quad$ For forming a grade, we should use analytical criteria defined by quality and level descriptions.

- These criteria should be familiar to students and, if there is any possibility, they should participate in their forming.

1.3.5. The grade should be explained.

- $\quad$ The teacher should explain the way of forming the grade to the students and their parents.

- The achieved results of the student should be explained from the aspect of subjective and objective circumstances and the teacher should give directions for further learning.

- When the teacher explains the results of the students, he/she should also take into consideration the weaknesses and fears of methodological grading.

1.3.6. Students and parents should be informed of their right to object to the grade.

- When students and their parents do not agree with the grade, it should be re-examined together with the teacher.

- $\quad$ Every remark should be considered and solved according to the law.

\subsection{ASSESSMENT HAS IMPACT ON STUDENT MOTIVATION AND LEARNING}

The nature of assessment influences the way and the degree of what is learned by students in the learning process. While some researches contend that assessments should be authentic, with feedback and opportunities for revision to improve, rather than simply audit learning, the more general principle is to understand how different assessments affect students. Will students be more engaged if assessment tasks are problem-based? How do students study when they know the test consists of multiple--choice items? What is the nature of feedback, and when is it given to students? How does assessment affect student effort?

Recent research, for example, shows that student self-assessment skills, learned and applied as part of formative assessment, enhance student achievement.

\subsection{QUALITATIVE ASSESSMENT IMPROVES EDUCATION QUALITY}

Just as assessment affects student learning and motivation, it also influences the nature of the educational quality on the class. When assessment is integrated with instruction, it informs teachers about what activities and assignments will be most useful, what level of teaching is most appropriate, and how summative assessments provide diagnostic information. During instructional activities, informal, formative assessment helps teachers know when to move on, when to ask more questions, when to give more examples, and how to respond to student questions. Standardized test scores, when used appropriately, help teachers understand student strengths and weaknesses in order to target further instruction.

\subsection{EFFICIENT ASSESSMENTS USE MULTIPLE METHODS}

Assessment which is objective is a series of measures that shows student understanding through multiple methods. A complete picture of what students understand and can do is put together in pieces comprised by different approaches to assessment. While testing experts and testing companies stress that important decision should not be made on the basis of a single test score, some educators at the local level seem determined to violate this principle.

There is a need to understand the entire range of assessment techniques and methods and their limitations.

\subsection{QUALITATIVE ASSESSMENT INCLUDES ADVANCED TECHNOLOGY}

As technology advances and teachers become more proficient in the use of technology, there will be increased opportunities for teachers to use computer--based techniques, Internet resources, and more complex, detailed ways of reporting results. There is, however, a danger that technology will contribute to the mindless use of new resources, such as using items online developed by some companies 
without adequate evidence of reliability, validity, and fairness, and software programs without sufficient thought about weighting, error, and averaging.

\section{CONCLUSION}

In conclusion, the assessment represents a process of accumulation, noting, interpreting, using information and announcing the improvement and achievement of the students in gaining knowledge, competencies and attitudes; so, what is most essential about it is to understand how general, fundamental assessment principles and ideas can be used to enhance student learning and teacher effectiveness. This will be achieved as teachers learn about conceptual and technical assessment concepts, methods, and procedures, for both large-scale and classroom assessments, and apply these fundamentals to instruction.

\section{References:}

[1] Popovski K. (1997). Psiholoski osnovi na sovremenata nastava, Skopje.

[2] Petkovski R., Georgievska G. (1995). Pat do poobjektivno ocenuvanje, Prosveten rabotnik, Skopje.

[3] Andrilovic, V., Cudina, M. (1985). Psihologija ucenja i nastave, Zagreb: Skolska knjiga.

[4] Klarin, M.V. (1995). Pedagoskata tehnologija vo nastavniot proces. Skopje: Pedagoski zavod na Makedonija.

[5] Erculj, J. (1996). Uceca se organizacija - odgovor na potrebe danasnje in utrisnje sole. Vzgoja in izobrazevanje, 5, Ljubljana. 